\title{
Hypocrisy and legitimacy in the aftermath of a scandal: an experimental study of stakeholder perceptions of nonfinancial disclosure
}

\author{
Marco Bellucci \\ Department of Economics and Management, University of Florence, Florence, Italy \\ Diletta Acuti \\ Department of Marketing, University of Portsmouth, Portsmouth, UK \\ Lorenzo Simoni \\ Department of Economics and Business Studies, University of Genoa, \\ Genoa, Italy, and \\ Giacomo Manetti \\ Department of Economics and Management, University of Florence, Florence, Italy
}

Hypocrisy and legitimacy in the aftermath of a scandal

Received 20 January 2021 Revised 28 April 2021 Accepted 3 May 2021

\begin{abstract}
Purpose - This study aims to investigate how stakeholders perceive the company's nonfinancial disclosure after a scandal has occurred. More specifically, the authors examine whether and how sustainability reporting practices in the aftermath of a scandal can influence the perceptions of stakeholders in terms of hypocrisy and legitimacy.

Design/methodology/approach - The present research represents a companion paper to another study in this issue that investigates the adaptation of companies' reporting behaviors after a scandal. The results of the initial qualitative study informed the subsequent quantitative study developed in this article. The authors build on the evidence of the main paper and perform a $2 \times 2$ between-subjects experiment to examine how stakeholders perceive the actions of companies that aim to restore their eroded legitimacy through social, environmental and sustainability (SES) reporting.

Findings - The results suggest that when companies take responsibility and develop remedial, socially responsible corporate activities are perceived as less hypocritical and more legitimate. Moreover, we show an interaction effect between taking responsibility and developing remedial socially responsible actions on hypocrisy and legitimacy perception.
\end{abstract}

(C) Marco Bellucci, Diletta Acuti, Lorenzo Simoni and Giacomo Manetti. Published by Emerald Publishing Limited. This article is published under the Creative Commons Attribution (CC BY 4.0) licence. Anyone may reproduce, distribute, translate and create derivative works of this article (for both commercial and non-commercial purposes), subject to full attribution to the original publication and authors. The full terms of this licence may be seen at http://creativecommons.org/licences/by/4.0/ legalcode

The authors sincerely thank Lee Parker and the two anonymous referees for their helpful comments during the review process. The authors are also grateful to Laura Grazzini, Valentina Mazzoli, Marta Pizzetti and Gabriele Pizzi for their expert advice on the experimental design. An early version of this study was presented at a seminar at the Free University of Bozen-Bolzano and the authors are thankful for the feedback received from Massimiliano Bonacchi and the attendants.

Although this study is the result of a team effort, Marco Bellucci can be considered the author of Sections 2.1 and 5; Diletta Acuti the author of Sections 3 and 4; Lorenzo Simoni the author of Section 2.2; and Giacomo Manetti the author of Sections 1 and 2.1.

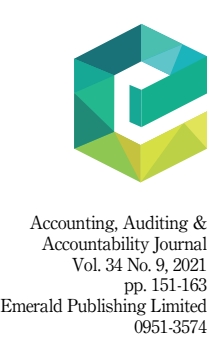

DOI 10.1108/AAAJ-01-2021-5113 
AAAJ

34,9

152

Originality/value - The present research takes advantage of an experimental design to investigate the effects of the adaptation of SES reporting from the perspective of stakeholders. The study provides insightful theoretical and practical implications for managers regarding how to handle a reputational loss and avoid perceptions of hypocrisy.

Keywords Corporate social responsibility, Hypocrisy, Legitimacy theory, Nonfinancial disclosure, Corporate scandal, Experiment

Paper type Research paper

\section{Introduction}

The emergence of corporate scandals and the use of corporate reporting to address or hide the consequences of such events have led scholars to examine how key stakeholder categories react to different disclosure patterns. While several studies have investigated companies' social, environmental and sustainability (SES) reports and have provided evidence of different behaviors, other studies have focused on how stakeholders perceive a company's image and reputation on the basis of nonfinancial disclosures (Axjonow et al., 2018; Diouf and Boiral, 2017).

Legitimacy theory has been widely used to explain companies' decisions to adopt a disclosure behavior characterized by transparency or enhanced disclosures (Dai et al., 2018). Corporate legitimacy consists of the perception that the actions of an entity are desirable, proper or appropriate within some socially constructed system of norms, values, beliefs and definitions (Suchman, 1995). Thus, obtaining legitimacy by aligning corporate behavior with stakeholder expectations and by shaping stakeholder perceptions is necessary to guarantee the corporation's survival and long-term value. This necessity has created an increased emphasis on effective nonfinancial disclosure as the means to gain organizational legitimacy (Campbell et al., 2003; Dube and Maroun, 2017). SES reporting plays a crucial role in legitimacy communication and preservation after a company has caused an accident, scandal or disaster. Generally, when a company faces corporate scandals and disasters, it responds to the threat of reputational damage by increasing corporate communications (Unerman, 2008; Corazza et al., 2020).

However, a critical issue emerges when a company aims to restore its image through SES reporting, which is related to potential hypocrisy. Although in some cases hypocrisy can be a normal and inevitable practice to handle conflicting demands, companies should redirect and control the stakeholder perceptions of hypocrisy (Christensen et al., 2020). Thus, companies need to balance their words carefully with their actions, avoiding the disclosure of signs of inauthenticity leading to accusations of hypocrisy from critical stakeholders (Beelitz and Merkl-Davies, 2012; Nielsen and Thomsen, 2018). The importance of an accurate disclosure strategy to manage stakeholder perceptions after a crisis resides in the consequences of such perceptions. Accordingly, positive stakeholder perceptions point toward the maintenance of organizational legitimacy, while negative perceptions could imply that the company legitimacy is at risk (She and Michelon, 2019).

This research aims to understand stakeholder perceptions of companies' legitimacy and hypocrisy after a scandal and how those perceptions are influenced by disclosure behaviors. We show that transparent disclosure, consisting of an admission of responsibility for the damage caused, and the illustration of remedial actions lead to companies being perceived as more legitimate and less hypocritical. We also document an interaction effect between these two dimensions. Hence, the effect of admission of responsibility on hypocrisy and legitimacy is stronger for companies that disclose remedial actions.

By shedding light on how stakeholders address corporate reporting when a scandal occurs, we contribute both to the literature on the perceptions of nonfinancial information and to the literature on how legitimacy is restored after a crisis. 
This paper is organized as follows. Section 2 reviews the literature and develops hypotheses. Section 3 illustrates the experimental design. Section 4 presents the results of the study. Section 5 highlights our main conclusions, limitations and further research.

This study is a companion paper to another article in this issue. Hence, it represents a development of the analysis conducted in the first paper, where we explore how companies adapt their sustainability reports after a scandal. In this paper, we provide evidence of how stakeholders perceive companies' responses to a scandal in terms of reporting, thus offering a wider picture of the consequences of SES scandals for both the companies and stakeholders involved.

\section{Literature}

\subsection{Stakeholder perceptions of corporate legitimacy and hypocrisy}

Hypocrisy occurs when a gap between assertions and actions begins to appear (Shklar, 1984). The term refers to the "motivation to appear moral yet, if possible, avoid the cost of actually being moral” (Batson et al., 2006, p. 321). Hampered accountability risks are engendering accusations of hypocrisy. This latter response occurs in a world in which values, ideas or people are in conflict, and it is a means for both individuals and organizations to address such conflict (Brunsson, 2007). In contrast, sincerity is interpreted as a "degree of congruence" that "does not relate to how ethical a company is but how true that company is to its mission statement, value declarations or corporate charter" (Fassin and Buelens, 2011, p. 587).

Recent research argues that firms use hypocritical talk, decisions and actions to manage divergent stakeholder interests and hence maintain legitimacy (Cho et al., 2015). The authors refer to "talk" as written or spoken words presenting organizations' commitments and policies to interact with the general and competitive environment and, in particular, with external stakeholders. While "decisions" are a special type of talk that indicates a future intention and an increased probability of corresponding actions (Brunsson, 2007), "actions" represent the execution of previous talk and decisions (Brunsson, 1993). Every "talk" contributes to building organizational façades, namely, symbolic appearance used to manage organizational legitimacy (Abrahamson and Baumard, 2008; Cho et al., 2015). More specifically, a "progressive façade" aims to show the organization's progress toward strategic goals, while a "reputational façade" illustrates the organization's positive images for stakeholders (Abrahamson and Baumard, 2008). In other words, organizations build façades to influence stakeholders' assessment of their social and institutional practices in an attempt to improve perceptions of the organization, and thereby managing its legitimacy (She and Michelon, 2019, p. 55).

This latter element, in turn, is a particularly valuable intangible asset for business success and even simply for the survival of an organization. Mitchell et al. (1997) argue that "legitimacy is a social good, it is something larger and more shared than a mere self-perception, and it may be defined and negotiated differently at various levels of social organization" (p. 867). In explaining their concept of legitimacy, the authors accept Weber's (1947) proposition that legitimacy and power are distinct attributes that can combine to create authority but that can exist independently as well. Mitchell et al. (1997) make use of Suchman's (1995) definition of organizational legitimacy, which is established when actions are perceived to be desirable according to social norms.

Lee et al. (2018) support the idea that legitimacy is determined by the way members of a society perceive, think about and feel toward an organization (see also: Hatch and Schultz, 1997). Even though companies may attempt to create legitimacy (Sonpar et al., 2010), if consumers, and stakeholders in general, do not accredit it, then their corporate social responsibility (CSR) efforts could be in vain (Palazzo and Scherer, 2006).
Hypocrisy and legitimacy in the aftermath of a scandal 
AAAJ 34,9

After a scandal, the corporate image is naturally compromised, but the methods of reaction to the scandal are decisive for rebuilding or definitively losing the organization's legitimacy and credibility: if stakeholders do not trust the corporation, then its reputation is damaged, as is its license to operate in society (Petty and Guthrie, 2000). Moreover, if reputation is damaged, relational capital is compromised (Casonato et al., 2019, p. 147; see also: de Castro et al., 2004). Once the license to operate is breached by a scandal, even shareholders and funders often sell their shares - causing share prices to plummet - or withdraw their credit lines. Therefore, a good reputation helps to maintain value, whereas a bad reputation tends to destroy it (Gatzert, 2015).

With reference to reporting as a legitimation tool, Kuruppu et al. (2019, p. 2081) sustain that the choice regarding whether direct action, reporting or a combination of both, should be used in organizational attempts to gain, maintain and manage legitimacy is affected by the visibility of the issue, the salience of the stakeholders involved and the stakeholder networks affected. For example, if an issue becomes public, a firm may need to take action and report to offer explanations or excuses.

This study contributes to understanding possible remedial actions that are effective not only for restoring the organizational façade and corporate image, thereby avoiding stakeholder perceptions of a gap between assertions and actions (hypocrisy in the sense of Batson et al., 2006), but also for rebuilding or reinforcing legitimacy through reporting action that is perceived to be desirable according to social norms (Suchman, 1995).

\subsection{Hypothesis development on remedial actions and admission of responsibility}

According to the literature on SES disclosure after a scandal, companies facing crises often develop CSR initiatives as a crisis strategy management response. However, this reactive approach necessitates caution, as when a corporation engages in CSR after a crisis, its CSR efforts may be viewed as an attempt to rectify the perception of corporate legitimacy and clear an eroded reputation.

Some companies decide to offer compensation to stakeholders affected by the damage through remedial CSR activities, whereas others disclose CSR activities that are not directly aimed at remedying the damage caused. Thus, companies implement CSR strategies that either do or do not fit with the damage they caused. The implementation of remedial or nonremedial CSR activities can affect stakeholders' responses. Indeed, how stakeholders interpret the relationship between the CSR initiative and the cause of the firm's hampered accountability could define their perceptions (García-Jiménez et al., 2017). This effect can be explained by stakeholders' attribution of motives that guide companies' behavior. According to attribution theory, CSR initiatives can have two different CSR motivations for implementation: intrinsic and extrinsic. When companies engage in CSR for intrinsic motives, stakeholders perceive the company as sincere, as they trust the "benevolent" character of the organization and the true values of the firm. In contrast, extrinsic CSR practices are those "perceived to be done to get something back or to avoid some kind of punishment from the community in general" (Story and Neves, 2015, p. 113). Therefore, if companies implement remedial CSR activities that attempt to remedy the damage they caused, they are perceived as sincere; as such activities reflect genuine concern. Conversely, the incongruence between CSR activity and the damage caused raises stakeholder skepticism over a company and its social projects, signaling the existence of an ulterior motive to engage in a CSR activity, such as appearing moral while avoiding the cost of being moral (Sen et al., 2006). Hence, if a company launches a CSR initiative in a different domain from the crisis issue, the CSR may not align with stakeholders' expectations that the company concentrate on addressing the crisis. By contrast, a CSR initiative in the same domain as the crisis issue would be considered consistent with the expectations of 
stakeholders, who recognize the company's genuine care about crisis problem solving (Kim and Choi, 2018).

We hypothesize that companies are perceived by stakeholders more positively when implementing a CSR initiative that is congruent with the cause of the specific disaster or scandal that eroded that company's legitimacy as follows:

H1. Companies are perceived as less hypocritical and more legitimate if they develop a remedial CSR activity.

Both impression management theory and account episodes theory identify the admission of responsibility-as well as offers of compensation-as a relevant component that enables the communication strategies of scandal-ridden companies to appear sincere, convincing and effective.

As information is necessary to change perceptions (Adams and Zutshi, 2004), a strategy that aims at improving a company's legitimacy and affecting external parties must be accompanied by disclosure.

In the field of psychology, hypocritical behavior is closely associated with the fundamental error of attribution (Polman and Ruttan, 2012). Individuals often try to explain and justify their behavior by attributing it to environmental and/or alien causes, while they often attribute the actions of others to innate characteristics. Some companies declare their responsibility for causing certain damage, whereas other companies prefer not to mention the violation they committed or not to assume their responsibility to avoid the risk of showing that their activities were unacceptable and inappropriate and that their social contract is not legitimate (Parmar et al., 2010). Thus, some companies decide not to share their responsibility for a negative event with stakeholders because doing so highlights failures and mistakes. However, recent studies have shown that disclosing bad news may be perceived as more credible than disclosing good news because management has less incentive to publish it when untrue, revealing weaker perceived hypocrisy of negative than positive information (Jahn and Brühl, 2019).

Since hypocritical behaviors derive from a gap between assertions and actions, companies that do not recognize their responsibility could be perceived as hypocritical by definition. For this reason, we expect companies to be perceived as hypocritical and less legitimate if they did not accept responsibility for their actions and as less hypocritical and more legitimate if they took responsibility for their actions.

Accordingly, we formally frame the following hypothesis regarding companies' behavior in relation to a crisis as follows:

H2. Companies are perceived as less hypocritical and more legitimate if they take responsibility.

Classical SES disclosure theories assume coherence among intentions, decisions and actions (Michelon et al., 2015). Discrepancies between SES disclosure and action can be viewed as a way for companies to attempt to ward off criticism and give false impressions of actual CSR practices (Schoeneborn et al., 2020).

If companies do not recognize their responsibilities but admit to developing remedial CSR activities, stakeholders might charge them with duplicity if they perceive the information as incoherent (Higgins et al., 2020). Thus, we expect that an interaction effect between the disclosure of remedial actions and the admission of fault exists. Hence, we formulate the hypothesis as follows:

H3. When companies develop a remedial CSR activity, they are perceived as more hypocritical and less legitimate if they do not admit their responsibility.
Hypocrisy and legitimacy in the aftermath of a scandal 
AAAJ

34,9

156

\section{Methodology}

We implement an experimental design to test our hypotheses on stakeholder perceptions of sustainability reports. Previous studies have used experiments to assess users' reactions to disclosures in SES reports (e.g. Kuruppu and Milne, 2010). We draw on prior literature to design the different cases related to remedial actions and admission of responsibility.

We developed an online $2 \times 2$ between-subjects experiment to investigate the effects of CSR actions (remedial CSR vs nonremedial CSR) and admission of responsibility (own attribution vs attribution to others) on perceptions of companies' hypocrisy and legitimacy by potential users of nonfinancial disclosure. Specifically, regarding the first variable, we considered the relationship between the CSR activities adopted by the company and the damage caused by the company, identifying "remedial" and "nonremedial" CSR activities. The second variable-the admission of responsibility-refers to the company's admission of its responsibility for the damage or its attribution of responsibility to an external cause.

The hypotheses were tested using the data collected through a questionnaire that was randomly distributed through the Prolific Academic (ProA) online crowdsourcing platform. ProA, which was launched in 2014, was selected because the literature claims that its participants produce higher-quality data than participants on other platforms, such as CrowdFlower and Amazon Mechanical Turk (Peer et al., 2017).

Because the study aimed to examine the influence of companies' admission of responsibility and CSR activities on hypocrisy and legitimacy perceptions, different stimuli were used to create four different scenarios. All scenarios involved a partial SES report page from a fictional company. We opted not to use scenarios referring to real companies because the resulting associations could have produced distortions that undermined our findings (McCarthy and Norris, 1999). However, we built on the existing literature on corporate scandals and on our content analysis of the 11 cases to present a realistic scenario. We manipulated the two variables via the contents of the SES report. The fictitious brand was presented in the cover story as follows:

TechAdvance is a German-based multinational information technology company founded in 1990 that currently has 121,000 employees. It produces a wide variety of consumer electronics products and appliances (including electronic kitchen appliances, personal computers, telephones, MP3 players, audio equipment, etc.).

Then, we specified that the company misused chemical substances, which gave 14 employees leukemia. A fictitious page of the corporate responsibility report that TechAdvance published at the end of 2017 was presented to respondents.

The admission of responsibility was manipulated by adopting the following sentences:

M1a. "As stated publicly several times by our CEO, the company is clear on its responsibilities related to the damages caused to its 14 employees."

M1b. "As stated publicly several times by our CEO, the company declines all responsibility and attributes the damages caused to its 14 employees to external causes."

To manipulate the CSR activity, we adopted the following sentences:

M2a. "During the year, we continued to meet our commitments to those affected. All legitimate claims for compensation have been and will continue to be met. By the end of 2011, US $\$ 5 \mathrm{~m}$ had been provided to the families of the employees who were the victims of this accident."

$M 2 b$. "TechAdvance has been working hard to improve its social responsibility and is helping the communities in Sri Lanka, where a part of the production is located, with the construction of a new school, investing US\$5m in this project.” 
The manipulation check of the cover story's contents was assessed by undertaking a preliminary test with a sample of 20 respondents that confirmed the perception of the gravity of the damage caused by the company. We asked respondents to rank the gravity of the violation on a seven-point Likert scale: the results show a mean of 6.10 , which is significantly different from 4 , the central value of the Likert scale $(p<0.01$; SD $=1.16)$. We also checked manipulations of the two independent variables by randomly providing the four scenarios developed for the experiment to a sample of 20 people through ProA. The admission of responsibility was tested by asking respondents to indicate the degree of agreement with the following two statements (with a seven-point Likert scale): "TechAdvance assumed its responsibility regarding the damage"; "TechAdvance communicated its responsibility for the damages caused to its 14 employees." The $T$-test of means confirmed the validity of the manipulation effect ( $p<0.01$ for both the statements). To test the CSR activity manipulation, we asked respondents to indicate the degree of agreement with the following two statements (with a seven-point Likert scale): "The remedy that TechAdvance implemented is related to the damage caused to its employees" and "The social remedy implemented by TechAdvance is related to the health issue caused to its employees." The $T$-test of means confirmed the validity of the manipulation effect $(p=0.02$ and $p=0.004$, respectively). Moreover, we consulted five other academic experts regarding this methodological approach to check our experimental design.

Perceived hypocrisy was measured with a six-item, seven-point Likert scale according to guidelines set out by Wagner et al. (2009). The Cronbach Alpha value for this scale is 0.88 . Organizational legitimacy was measured with Bachmann and Ingenhoff's three-item, sevenpoint Likert scale (2016). The Cronbach Alpha value for this scale is 0.89 . See Table 1 for measures and properties of the constructs.

The experiment was conducted in July 2018 and involved a sample of 281 participants, who were randomly assigned to scenarios. Respondents were pre-screened according to the following three criteria. The first was age: the questionnaire was sent only to people aged between 22 and 65 . This criterion allowed us to orient the study to the age range of people familiar with the industry in which the fictitious company operated and potential users of its nonfinancial disclosure. Second, only participants with English as their native language were included; this ensured that the respondents understood the text of the questionnaire and the
Hypocrisy and legitimacy in the aftermath of a scandal

\begin{tabular}{|c|c|c|c|c|}
\hline Constructs & Source & Item & & $\begin{array}{c}\text { Cronbach } \\
\text { alpha }\end{array}$ \\
\hline $\begin{array}{l}\text { Perceived } \\
\text { hypocrisy }\end{array}$ & $\begin{array}{l}\text { Wagner et al. } \\
(2009)\end{array}$ & $\begin{array}{l}(1) \\
(2) \\
(3) \\
(4) \\
(5) \\
(6)\end{array}$ & $\begin{array}{l}\text { TechAdvance acts hypocritically } \\
\text { What TechAdvance says and does are two } \\
\text { different things } \\
\text { TechAdvance pretends to be something that } \\
\text { it is not } \\
\text { TechAdvance does exactly what it says }{ }^{\mathrm{a}} \\
\text { TechAdvance keeps its promises } \\
\text { TechAdvance puts its words into action }\end{array}$ & 0.88 \\
\hline $\begin{array}{l}\text { Organizational } \\
\text { legitimacy }\end{array}$ & $\begin{array}{l}\text { Bachmann and } \\
\text { Ingenhoff (2016) }\end{array}$ & $\begin{array}{l}(1) \\
(2) \\
(3)\end{array}$ & $\begin{array}{l}\text { It seems to me that TechAdvance acts } \\
\text { consistently with socially accepted norms } \\
\text { and values } \\
\text { In my opinion, TechAdvance seems to be a } \\
\text { legitimate company } \\
\text { I have the impression that TechAdvance } \\
\text { complies with social standards }\end{array}$ & 0.89 \\
\hline
\end{tabular}

Note(s): ${ }^{a}$ Item responses were reverse coded

(1) TechAdvance acts hypocritically

0.88

different things

it is not

(5) TechAdvance keeps its promises ${ }^{\mathrm{a}}$

(6) TechAdvance puts its words into action ${ }^{\mathrm{a}}$

(1) It seems to me that TechAdvance acts consistently with socially accepted norms and values

legitimate company

complies with social standards

Table 1.

Measures and properties of constructs (experiment) 
AAAJ

34,9

\section{8}

Figure 1.

Stakeholders' perceptions of company's hypocrisy stimuli. Third, because of the influence of culture on individuals' behavior, we selected only British respondents.

The sample included 100 men (36\%) and 181 women (64\%). Among them, 52\% were between 22 and 34 years of age, $25 \%$ were between 35 and 44 years of age, $13 \%$ were between 45 and 54 years of age and 10\% were between 55 and 64 years of age.

\section{Results}

After the data collection, we tested our hypotheses by performing an analysis of variance (ANOVA) using IBM SPSS software.

As illustrated in Figures 1 and 2, the effect of CSR activities on perceived hypocrisy $(F=4.584 ; p=0.033)$ and legitimacy $(F=8.417 ; p=0.004)$ is significant. Subjects exposed to the "remedial CSR" scenario perceived a lower level of hypocrisy $(M=4.163 ; \mathrm{SE}=0.096)$ and a higher level of legitimacy $(M=4.459$; $\mathrm{SE}=0.100)$ than subjects exposed to the "nonremedial CSR" scenario (hypocrisy: $M=4.066$; $\mathrm{SE}=0.113$ and legitimacy: $M=3.590$; $\mathrm{SE}=0.119$ ). The results validate our first hypothesis that companies are perceived as less hypocritical and more legitimate if they develop a remedial CSR activity (H1).

\section{Hypocrisy perception}

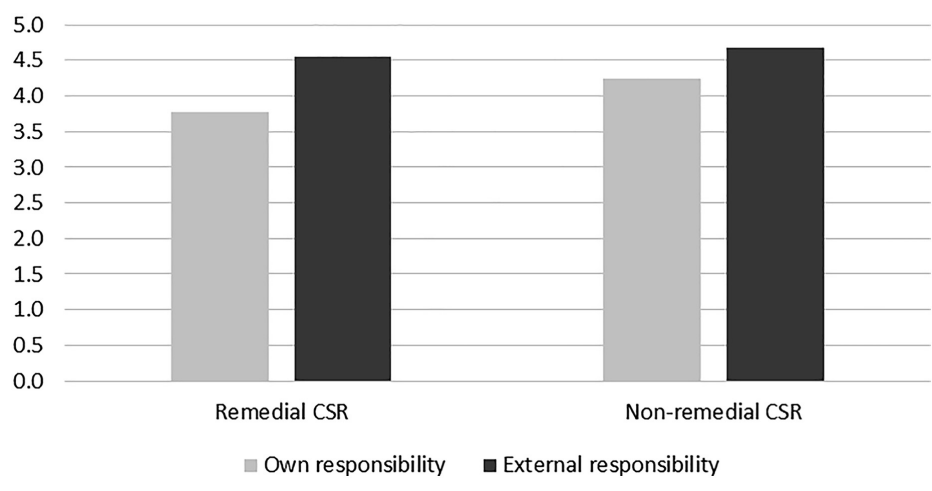

\section{Legitimacy perception}

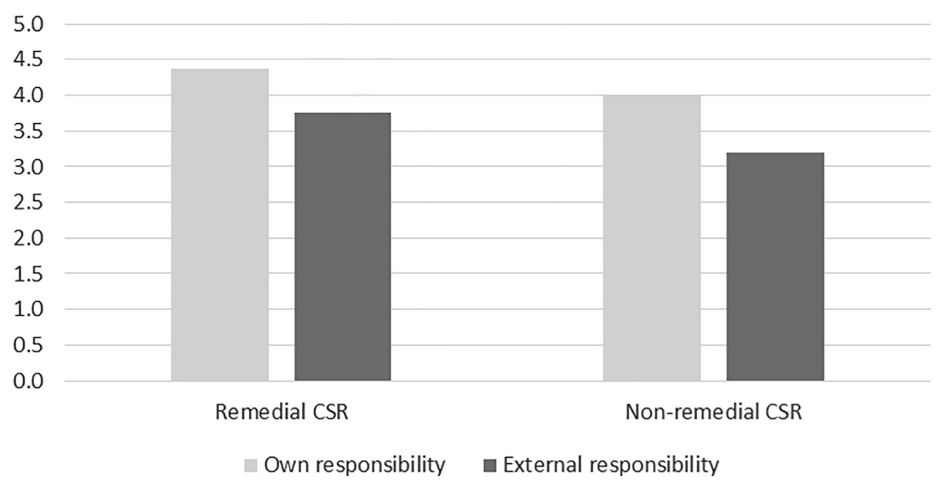

Figure 2.

Stakeholders' perceptions of a company's legitimacy 
The effect of admission of responsibility on perceived hypocrisy $(F=19.704 ; p<0.01)$ and legitimacy $(F=18.082 ; p<0.01)$ is significant. Subjects exposed to the "admission of responsibility" scenario perceived a lower level of hypocrisy $(M=4.004 ; \mathrm{SE}=0.094)$ and a higher level of legitimacy $(M=4.177 ; \mathrm{SE}=0.112)$ than subjects exposed to the "attribution of responsibility to external causes" scenario (hypocrisy: $M=4.618 ; \mathrm{SE}=0.101$ and legitimacy: $M=3.479$; $\mathrm{SE}=0.120$ ). Hence, the results provide support for our second hypothesis that companies are perceived as less hypocritical and more legitimate if they take responsibility $(\mathrm{H} 2)$.

The third hypothesis (H3: when companies develop a remedial CSR activity, they are perceived as more hypocritical and less legitimate if they do not recognize their responsibility) is confirmed by a pairwise comparison that is significant for hypocrisy $(\phi<0.01 ; \mathrm{SE}=0.191)$ and for legitimacy $(\phi=0.009 ; \mathrm{SE}=0.227)$. Indeed, when the company adopts a remedial CSR, it is perceived as more hypocritical $(M=4.559 ; \mathrm{SE}=0.134)$ and less legitimate $(M=3.766 ; \mathrm{SE}=0.159)$ if it does not recognize its responsibility compared with the scenario in which it recognizes its responsibility (hypocrisy: $M=3.768$; $\mathrm{SE}=0.137$ and legitimacy: $M=4.366$; $\mathrm{SE}=0.162$ ).

\section{Conclusions}

In this paper, we investigate how stakeholders perceive companies' nonfinancial disclosure after a scandal and whether and how sustainability reporting practices in such an aftermath can influence stakeholder perceptions in terms of hypocrisy and legitimacy. Our methodology aims at understanding how stakeholders perceive the actions of companies that aim to restore their eroded legitimacy after a scandal through SES reporting. In this sense, the paper contributes to the understanding of possible remedial actions that are effective for avoiding stakeholder perceptions of a gap between assertions and actions (Batson et al., 2006).

This paper has value for investigating the adaptation of SES reporting from the integrated perspective of both organizations and their stakeholders. Given the emphasis on accountability and CSR, it is increasingly relevant for business research to contribute to the understanding of the connection between SES reporting and stakeholder perceptions. Even though accounts are one of the few managerial tools to mitigate negative outcomes during a crisis, little research has successfully investigated the effects of different crisis accounts on stakeholder reactions (McDonald et al., 2010). As responses become more accommodating to stakeholders, they become more expensive (Stockmyer, 1996): the success of less-accommodative accounts would provide practitioners with lower-cost communication options, but the results of our experiment support the view that companies are perceived as less hypocritical when they develop a remedial CSR activity and when they take responsibility. Given that potential users of nonfinancial disclosure can implement boycotting behaviors if they perceive a loss of corporate legitimacy, research investigating their legitimacy perceptions is important (Kates, 2004; Kozinets, 2002; Hu et al., 2018). Attribution theory predicts that voluntarily reporting negative information is likely to be attributed to a company's honesty (Jahn and Brühl, 2019). In this light, our experiment suggests that avoiding clear responsibility, omitting negative information and developing CSR activities unlinked to the issues of the core business appear to violate the implicit terms of the social contract and lead to a perception of hypocrisy.

We show that stakeholders perceive companies that admit their responsibility as less hypocritical and more legitimate. This evidence suggests to managers that stakeholders can appreciate a disclosure that highlights failures or mistakes, especially for voluntary disclosures. In contrast, stakeholders negatively evaluate a statement that avoids or denies responsibility; thus, managers should use their sustainability reporting to inform
Hypocrisy and legitimacy in the aftermath of a scandal 
AAAJ

34,9

160

stakeholders about particular events that occur even if they seem to negatively affect a company's reputation. This transparency is important because the consequent perception of companies' legitimacy is related to other crucial factors. For instance, companies with a high level of legitimacy can improve their relationships with and gain the support of their stakeholders. In contrast, low levels of legitimacy can increase the risk of losing market share, and thus, damage corporate profitability (Li et al., 2017).

A recommendation that emerges from this research is related to CSR remedial activities. As illustrated by the results of the experiment, remedial and other CSR activities are appreciated when they are considered coherent with the specific issue but are considered illegitimate and hypocritical otherwise. After a scandal, the corporate reputation is inevitably compromised but how organizations react to the scandal is crucial in determining their legitimacy. This finding implies the need for organizations to design CSR activities that are genuinely linked with improvements in the managerial system that caused or failed to prevent the scandal. The design of CSR activities should also be coherent with the admission of responsibility. In this vein, managers should strictly integrate their CSR actions and disclosure choices. Indeed, a gap between actions and assertions defines, and thus causes stakeholders' perception of hypocrisy and, at the same time, delegitimizes their rights to operate.

This study has some limitations with regard to the research design for examining stakeholder perceptions. We could not distinguish among the opinions of different stakeholders, and we focused on a general category of "potential users of nonfinancial disclosure." Further research could focus on the different expectations of different categories of internal and external stakeholders. Stakeholders' perceptions can change depending on the group to which they belong and the impact of the damage caused by the company on such a group. Stakeholders who are directly affected by the damage caused by the company may be more engaged and interested in the company disclosure and more sensitive in the evaluation of companies' remedial action and, thus in the detection of any sign of hypocrisy.

Moreover, although this research focuses on the role of companies' communication strategies, we recognize the impact that counter accounts can have on stakeholder perceptions. Therefore, we encourage further research to include counter accounts in new experimental designs and observe how they affect stakeholders' reactions.

\section{References}

Abrahamson, E. and Baumard, P. (2008), "What lies behind organizational façades and how organizational façades lie: an untold story of organizational decision making", The Oxford Handbook of Organizational Decision Making, Oxford University Press, Oxford, pp. 437-452.

Adams, C. and Zutshi, A. (2004), "Corporate social responsibility: why business should act responsibly and be accountable", Australian Accounting Review, Vol. 14 No. 34, pp. 31-39.

Axjonow, A., Ernstberger, J. and Pott, C. (2018), "The impact of corporate social responsibility disclosure on corporate reputation: a non-professional stakeholder perspective", Journal of Business Ethics, Vol. 151 No. 2, pp. 429-450.

Bachmann, P. and Ingenhoff, D. (2016), "Legitimacy through CSR disclosures? The advantage outweighs the disadvantages", Public Relations Review, Vol. 42 No. 3, pp. 386-394.

Batson, C.D., Collins, E. and Powell, A.A. (2006), "Doing business after the fall: the virtue of moral hypocrisy", Journal of Business Ethics, Vol. 66 No. 4, pp. 321-335.

Beelitz, A. and Merkl-Davies, D.M. (2012), "Using discourse to restore organizational legitimacy: 'CEO-speak' after an incident in a German nuclear power plant”, Journal of Business Ethics, Vol. 108 No. 1, pp. 101-120.

Brunsson, N. (1993), "Ideas and actions: justification and hypocrisy as alternatives to control", Accounting, Organizations and Society, Vol. 18 No. 6, pp. 489-506. 
Brunsson, N. (2007), The Consequences of Decision-Making, Oxford University Press, Oxford.

Campbell, D., Craven, B. and Shrives, P. (2003), "Voluntary social reporting in three FTSE sectors: a comment on perception and legitimacy", Accounting, Auditing and Accountability Journal, Vol. 16 No. 4, pp. 558-581.

Casonato, F., Farneti, F. and Dumay, J. (2019), "Social capital and integrated reporting: losing legitimacy when reporting talk is not supported by actions", Journal of Intellectual Capital, Vol. 20 No. 1, pp. 144-164.

Cho, C.H., Laine, M., Roberts, R.W. and Rodrigue, M. (2015), "Organized hypocrisy, organizational façades, and sustainability reporting", Accounting, Organizations and Society, Vol. 40, pp. 78-94.

Christensen, L.T., Morsing, M. and Thyssen, O. (2020), "Timely hypocrisy? Hypocrisy temporalities in CSR communication”, Journal of Business Research, Vol. 114, pp. 327-335.

Corazza, L., Truant, E., Scagnelli, S.D. and Mio, C. (2020), "Sustainability reporting after the Costa Concordia disaster: a multi-theory study on legitimacy, impression management and image restoration", Accounting, Auditing and Accountability Journal, Vol. 33 No. 8, pp. 1909-1941.

Dai, N.T., Du, F., Young, S.M. and Tang, G. (2018), "Seeking legitimacy through CSR reporting: evidence from China”, Journal of Management Accounting Research, Vol. 30 No. 1, pp. 1-29.

de Castro, G.M., Sáez, P.L. and López, J.E.N. (2004), "The role of corporate reputation in developing relational capital", Journal of Intellectual Capital, Vol. 5 No. 4, pp. 575-585.

Diouf, D. and Boiral, O. (2017), "The quality of sustainability reports and impression management", Accounting, Auditing and Accountability Journal, Vol. 30 No. 3, pp. 643-667.

Dube, S. and Maroun, W. (2017), "Corporate social responsibility reporting by South African mining companies: evidence of legitimacy theory", South African Journal of Business Management, Vol. 48 No. 1, pp. 23-34.

Fassin, Y. and Buelens, M. (2011), "The hypocrisy-sincerity continuum in corporate communication and decision making: a model of corporate social responsibility and business ethics practices", Management Decision, Vol. 49 No. 4, pp. 586-600.

García-Jiménez, J.V., Ruiz-de-Maya, S. and López-López, I. (2017), “The impact of congruence between the CSR activity and the company's core business on consumer response to CSR", Spanish Journal of Marketing-ESIC, Vol. 21, pp. 26-38.

Gatzert, N. (2015), "The impact of corporate reputation and reputation damaging events on financial performance: empirical evidence from the literature", European Management Journal, Vol. 33 No. 6, pp. 485-499.

Hatch, M.J. and Schultz, M. (1997), "Relations between organizational culture, identity and image", European Journal of Marketing, Vol. 31 Nos 5-6, pp. 356-365.

Higgins, C., Tang, S. and Stubbs, W. (2020), "On managing hypocrisy: the transparency of sustainability reports", Journal of Business Research, Vol. 114, pp. 395-407.

Hu, M., Qiu, P., Wan, F. and Stillman, T. (2018), "Love or hate, depends on who's saying it: how legitimacy of brand rejection alters brand preferences", Journal of Business Research, Vol. 90, pp. 164-170.

Jahn, J. and Brühl, R. (2019), "Can bad news be good? On the positive and negative effects of including moderately negative information in CSR disclosures", Journal of Business Research, Vol. 97, pp. 117-128.

Kates, S.M. (2004), "The dynamics of brand legitimacy: an interpretive study in the gay men's community", Journal of Consumer Research, Vol. 31 No. 2, pp. 455-464.

Kim, S. and Choi, S.M. (2018), "Congruence effects in post-crisis CSR communication: the mediating role of attribution of corporate motives", Journal of Business Ethics, Vol. 153 No. 2, pp. 447-463.

Kozinets, R.V. (2002), "Can consumers escape the market? Emancipatory illuminations from burning man", Journal of Consumer Research, Vol. 29 No. 1, pp. 20-38.
Hypocrisy and legitimacy in the aftermath of a scandal 
Kuruppu, S.C. and Milne, M.J. (2010), “Dolphin deaths, organizational legitimacy and potential empoyees' reactions to assured environmental disclosures", Accounting Forum, Vol. 34 No. 1, pp. 1-19.

Kuruppu, S.C., Milne, M.J. and Tilt, C.A. (2019), "Gaining, maintaining and repairing organisational legitimacy”, Accounting, Auditing and Accountability Journal, Vol. 32 No. 7, pp. 2062-2087.

Lee, Y.J., Yoon, H.J. and O'Donnell, N.H. (2018), "The effects of information cues on perceived legitimacy of companies that promote corporate social responsibility initiatives on social networking sites”, Journal of Business Research, Vol. 83, pp. 202-214.

Li, J., He, H., Liu, H. and Su, C. (2017), "Consumer responses to corporate environmental actions in China: an environmental legitimacy perspective", Journal of Business Ethics, Vol. 143 No. 3, pp. 589-602.

McCarthy, M.S. and Norris, D.G. (1999), "Improving competitive position using branded ingredients", The Journal of Product and Brand Management, Vol. 8 No. 4, pp. 267-285.

McDonald, L.M., Sparks, B. and Glendon, A.I. (2010), "Stakeholder reactions to company crisis communication and causes”, Public Relations Review, Vol. 36 No. 3, pp. 263-271.

Michelon, G., Pilonato, S. and Ricceri, F. (2015), "CSR reporting practices and the quality of disclosure: an empirical analysis", Critical Perspectives on Accounting, Vol. 33, pp. 59-78.

Mitchell, R.K., Agle, B.R. and Wood, D.J. (1997), "Toward a theory of stakeholder identification and salience: defining the principle of who and what really counts", Academy of Management Review, Vol. 22, pp. 853-886.

Nielsen, A.E. and Thomsen, C. (2018), "Reviewing corporate social responsibility communication: a legitimacy perspective", Corporate Communications: An International Journal, Vol. 23 No. 4, pp. 492-511.

Palazzo, G. and Scherer, A.G. (2006), "Corporate legitimacy as deliberation: a communicative framework", Journal of Business Ethics, Vol. 66 No. 1, pp. 71-88.

Parmar, B., Freeman, R., Harrison, J., Wicks, A., Purnell, L. and De Colle, S. (2010), "Stakeholder theory: the state of the art", The Academy of Management Annals, Vol. 4 No. 1, pp. 403-445.

Peer, E., Brandimarte, L., Samat, S. and Acquisti, A. (2017), "Beyond the Turk: alternative platforms for crowdsourcing behavioral research", Journal of Experimental Social Psychology, Vol. 70, pp. 153-163.

Petty, R. and Guthrie, J. (2000), "Intellectual capital literature review: measurement, reporting and management”, Journal of Intellectual Capital, Vol. 1 No. 2, pp. 155-176.

Polman, E. and Ruttan, R.L. (2012), "Effects of anger, guilt, and envy on moral hypocrisy", Personality and Social Psychology Bulletin, Vol. 38 No. 1, pp. 129-139.

Schoeneborn, D., Morsing, M. and Crane, A. (2020), "Formative perspectives on the relation between CSR communication and CSR practices: pathways for walking, talking, and t (w) alking", Business and Society, Vol. 59 No. 1, pp. 5-33.

Sen, S., Bhattacharya, C.B. and Korschun, D. (2006), "The role of corporate social responsibility in strengthening multiple stakeholder relationships: a field experiment", Journal of the Academy of Marketing Science, Vol. 34 No. 2, pp. 158-166.

She, C. and Michelon, G. (2019), "Managing stakeholder perceptions: organized hypocrisy in CSR disclosures on Facebook", Critical Perspectives on Accounting, Vol. 61, pp. 54-76.

Shklar, J. (1984), Ordinary Vices, Harvard University Press, Cambridge.

Sonpar, K., Pazzaglia, F. and Kornijenko, J. (2010), "The paradox and constraints of legitimacy", Journal of Business Ethics, Vol. 95 No. 1, pp. 1-21.

Stockmyer, J. (1996), "Brands in crisis: consumer help for deserving victims", Advances in Consumer Research, Vol. 13, pp. 429-435.

Story, J. and Neves, P. (2015), "When corporate social responsibility (CSR) increases performance: exploring the role of intrinsic and extrinsic CSR attribution”, Business Ethics: A European Review, Vol. 24 No. 2, pp. 111-124. 
Suchman, M.C. (1995), "Managing legitimacy: strategic and institutional approaches", Academy of Management Review, Vol. 20 No. 3, pp. 571-610.

Unerman, J. (2008), "Strategic reputation risk management and corporate social responsibility reporting", Accounting, Auditing and Accountability Journal, Vol. 21 No. 3, pp. 362-364.

Wagner, T., Lutz, R.J. and Weitz, B.A. (2009), "Corporate hypocrisy: overcoming the threat of inconsistent corporate social responsibility perceptions", Journal of Marketing, Vol. 73, pp. 77-91.

Weber, M. (1947), The Theory of Social and Economic Organization, Free Press, New York.

Hypocrisy and legitimacy in the aftermath of a scandal

\section{About the authors}

Marco Bellucci (PhD) is an assistant professor of accounting in the Department of Economics and Management at the University of Florence. His research interests include sustainability reporting, corporate social responsibility, stakeholder engagement, social enterprises, nonprofit organizations and accounting history.

Diletta Acuti $(\mathrm{PhD})$ is a senior lecturer in marketing at the University of Portsmouth. Her research interests include sustainable consumer behavior and corporate social responsibility.

Lorenzo Simoni $(\mathrm{PhD})$ is a research fellow in accounting in the Department of Economics and Business Studies at the University of Genoa. His research interests include business model disclosure, nonfinancial information, key performance indicators, risk reporting and earnings quality.

Giacomo Manetti $(\mathrm{PhD})$ is a professor of accounting in the Department of Economics and Management at the University of Florence. His research interests include stakeholder theory, corporate social responsibility, sustainability reporting and assurance, the third sector and accounting history. Giacomo Manetti is the corresponding author and can be contacted at: giacomo.manetti@unifi.it

For instructions on how to order reprints of this article, please visit our website: 